\title{
A New Onset Paranoid Psychosis Associated With Fluoxetine and Bupropion: A Case Report
}

\author{
Vassili V. Arkadiev M.D. \\ MetroHealth Medical Center, Case Western Reserve University, Cleveland, $\mathrm{OH}$ \\ Stephen L. Ruedrich M.D. \\ Case Western Reserve University, Cleveland, $\mathrm{OH}$
}

Follow this and additional works at: https://jdc.jefferson.edu/jeffjpsychiatry

Part of the Psychiatry Commons

Let us know how access to this document benefits you

\section{Recommended Citation}

Arkadiev, Vassili V. M.D. and Ruedrich, Stephen L. M.D. (2002) "A New Onset Paranoid Psychosis Associated With Fluoxetine and Bupropion: A Case Report," Jefferson Journal of Psychiatry. Vol. 17 : Iss. 1 , Article 7. DOI: https://doi.org/10.29046/JJP.017.1.008

Available at: https://jdc.jefferson.edu/jeffjpsychiatry/vol17/iss1/7

This Article is brought to you for free and open access by the Jefferson Digital Commons. The Jefferson Digital Commons is a service of Thomas Jefferson University's Center for Teaching and Learning (CTL). The Commons is a showcase for Jefferson books and journals, peer-reviewed scholarly publications, unique historical collections from the University archives, and teaching tools. The Jefferson Digital Commons allows researchers and interested readers anywhere in the world to learn about and keep up to date with Jefferson scholarship. This article has been accepted for inclusion in Jefferson Journal of Psychiatry by an authorized administrator of the Jefferson Digital Commons. For more information, please contact: JeffersonDigitalCommons@jefferson.edu. 


\title{
Letters to the Editor
}

\author{
A NEW ONSET PARANOID PSYCHOSIS ASSOCIATED WITH FLUOXETINE AND \\ BUPROPION: A CASE REPORT
}

To the editor: Bupropion, a unicyclic aminoketone, has a chemical structure that is unique among antidepressants (1). Bupropion also has a relatively favorable side effect profile (2); but occasional severe side effects, including delirium and psychoses, have been reported (2-11). We present a patient who appeared to have a bupropion-induced psychotic disorder, with almost exclusively delusional symptomatology.

Ms. A was a 45 year old single African-American mother of two when she was seen in the outpatient psychiatric clinic for depression. Her medical history was significant for obesity, diabetes type 2, and osteoarthritis, for which she took glyburide $5 \mathrm{mg} /$ day and ibuprofen 1600 $\mathrm{mg} /$ day. In her late 30 's, Ms. A had her uterus removed secondary to uterine fibroids; she subsequently had very mild postmenopausal symptoms, which lasted for less than a year. Her medical condition was stable, with blood glucose ranging between $150-200 \mathrm{mg} / \mathrm{dl}$. Her hemoglobin Alc was between 6.4 and 9.3\%. Blood count, electrolytes, TSH, T4, urinalysis, and liver function tests were normal. Her HDL were $34 \mathrm{mg} / \mathrm{dl}$ (normal range 35 and higher) and cholesterol/HDL ratio was 5.38 (normal range 0.00-4.44).

Ms. A had no previous history of psychiatric inpatient treatment, suicide attempt, mania, psychosis or confusion, and no history of drug or alcohol use. Her family history was significant for schizophrenia in her older sister, who had died of myocardial infarction, and a history of depression in the younger sister, who was taking an unknown psychiatric medication.

Ms. A had graduated from high school, and for more than 20 years worked as a nursing assistant. She had been married and divorced twice, has two children, and lives with her youngest daughter. Ms. A's first depressive episode occurred at the age of 43; apparently not provoked by any external or physical stressor. Her condition had gradually deteriorated to the point that she had been unable to work, and had to quit her job. Most of the time she remained in bed, and became socially withdrawn, which was completely different from her premorbid personality. After approximately ten months of depressive symptoms, Ms. A was referred by her internist to the outpatient psychiatric clinic. According to the patient's medical record, she had demonstrated depressed mood, depressive cognition, vegetative symptoms of depression, motor retardation, and impaired concentration. She was treated initially with fluoxetine $20 \mathrm{mg}$ per day, with gradual titration to $60 \mathrm{mg} /$ day over the next 8 weeks. Ms. A responded to the higher dose with significant improvement in her mood, alleviation of motor retardation, improvement in her cognition, and significant improvement in her vegetative symptoms as

Vassili Valerievich Arkadiev, MD, PGY-III Resident in Psychiatry, MetroHealth Medical Center, Case Western Reserve University, Cleveland, OH

Stephen Lawrence Ruedrich, MD, Associate Professor of Psychiatry, Case Western Reserve University, Cleveland, $\mathrm{OH}$

Correspondence to: Dr. V. Arkadiev, MetroHealth Medical Center, Cleveland, OH, 44109, Tel.: 216 7784428, Fax: 216 7788412, email: varkad@yahoo.com 
well. Over the next several months, while she continued to take $60 \mathrm{mg}$ of fluoxetine daily, Ms. A did well. She became more social, was helping her family as she had done before the depression, and even returned to work.

After five months of treatment with $60 \mathrm{mg}$ of fluoxetine daily, Ms. A had stopped the medication, and dropped out of treatment. She remained asymptomatic for another four months, when she redeveloped depressive symptoms, and was seen again at our outpatient clinic. On exam Ms. A had depressed mood, psychomotor retardation, low energy level, severe anhedonia, initial and middle insomnia, hopelessness, helplessness, self -depreciation, and ruminative thoughts. Her cognitive exam was normal, and she had no psychotic symptoms. Fluoxetine was restarted and titrated to $80 \mathrm{mg}$ /day over the next 2 months. She remained on $80 \mathrm{mg} /$ day for 5 weeks, without significant improvement, at which time bupropion SR was added to her fluoxetine regimen, at $50 \mathrm{mg}$ /day. After 3 days bupropion was increased to 100 $\mathrm{mg} /$ day. On the $3 \mathrm{rd}$ day of treatment with bupropion $100 \mathrm{mg}$ a day, Ms. A developed ideas that people were talking about her, strangers on the streets were watching her, and she felt reluctant to leave her house. On the $7^{\text {th }}$ day of bupropion treatment Ms. A was re-evaluated as an outpatient. Her exam at that time revealed no significant impairment in orientation, concentration, or memory. She had delusional ideas of reference (as above) and no insight into her psychotic symptoms. She reported her mood to be better, and her affect was less depressed, with no hopelessness, or helplessness. Her energy was also better, as was her appetite. No manic symptoms were observed. The bupropion was discontinued, and Ms. A was given risperidone $1.5 \mathrm{mg}$ bid. She took only one dose, then stopped the antipsychotic medication secondary to severe sedation. Over the next 7 days, her psychotic symptoms resolved completely, but she began to experience an exacerbation of her depressive symptoms. Three weeks later her fluoxetine was stopped, and Ms. A was switched to venlafaxine. On follow up after 3 months, Ms. A had mild depressive symptoms, no psychotic symptoms, and no cognitive impairment.

The mechanism of action of bupropion is not well understood (1); however, it is believed that the antidepressant effect, and possibly some side effects, are due to norepinephrine turnover, and to lesser extent, dopamine reuptake blockade $(1,2)$. There have been several case reports of apparent bupropion-associated psychosis (2-11), however, most of the patients who developed psychosis while taking bupropion had a history of psychosis prior to bupropion treatment. Some of these reports describe not only pathology of thought processes, and perceptual disturbances, but also definite cognitive impairment with clouded consciousness. We were able to identify only 3 reports of psychotic symptoms in the absence of cognitive impairment in non-predisposed individuals following bupropion treatment ( 2 cases of hallucinations, and one case of delusions and hallucinations) (9-11). To our knowledge, no reports described pure delusional psychosis without perceptual disturbances. Additionally, all of the reports of bupropion-induced psychosis and bupropion-induced delirium involved daily doses in the range of $300 \mathrm{mg}$ and above (2-10). In our patient, the maximum dose did not exceed 100 $\mathrm{mg} /$ day of bupropion SR.

Bupropion undergoes extensive hepatic metabolism, mainly through the CYP 450 IIB6 and IIIA3/4 systems (15); the latter of which is known to be suppressed by fluoxetine $(14,15)$. Bupropion does not appear to be metabolized by IID6 isoenzymes; however, there are some data that bupropion and its metabolites may inhibit IID6 (14), which is a secondary metabolic pathway for fluoxetine. Bupropion metabolites may be elevated in people with hepatic disease and in the elderly, which may be contributory to side effects $(10,15)$. In our patient, the 
significant improvement in her mood began after several days of treatment with bupropion, at approximately the same time that she started experiencing delusions. Both her mood improvement, as well as psychotic symptoms, might be attributed to an increased level of bupropion metabolites.

Alternatively, the phenomena of drug-associated delusions might be explained by serotonergic mechanisms. Fluoxetine increases ventral striatal serotonin (17), stimulating 5-HT3 receptor-mediated dopamine release in the ventral striatal region, which may lead to psychosis (18). Underleider and Pechnick (19), in reviewing the mechanisms of action of hallucinogens, concluded that these agents work through effects at 5-HT2 receptors. However, Pierce and Peroutka (20) suggested that action at 5-HT1C, and not 5-HT2 receptors, may account for the hallucinogenic properties. Among several reports describing fluoxetine and psychoses, (18,2124) we were able to identify only one case of possible fluoxetine-induced persecutory delusions in a patient who did not have previous history of psychosis (20); as well as 3 reports of visual hallucinosis (22-24). One of those patients was also taking L-dopa, and another developed visual hallucinosis after dextromethorphan had been added to her regimen. Although it is possible to attribute Ms. A's psychotic symptoms to elevated levels of fluoxetine, caused by bupropion-associated 2D6 inhibition, we believe that it is unlikely, since the CYPIID6 system is only a minor pathway for fluoxetine (13).

One other possible explanation for the development of psychotic symptoms in Ms. A would be a so-called "schizoaffective evolution" in the course of her affective illness. Although Ms. A had a family history of schizophrenia and depression, we think this is extremely unlikely, due to the short symptomatic period of the delusions (about 8 days), their disappearance without specific antipsychotic treatment, the obvious temporal relationship with the initiation of bupropion treatment, and the lack of negative symptoms between her depressive episodes.

Of additional interest was Ms. A's initial response to fluoxetine, but lack of response to the same medication when it was restarted, even at increased dose. The development of tolerance to the therapeutic effects of SSRI's, which Goodnick and Goldstein (25) have termed "neurophysiological tolerance", is a well-known phenomena, and has been reported elsewhere (25-31). Fava et al (26) in their study of re-initiation of antidepressant treatment in patients who previously responded to fluoxetine, but later were switched to placebo and relapsed, found that $38 \%$ of the patients did not respond to the re-initiation of fluoxetine. Michelson et al (29) reported that fluoxetine occasionally lost efficacy after 9 months of continued treatment, following response to $12-14$ weeks of initial treatment. Fava et al., (30) reported that relapse or recurrence of depressive symptoms occurring in patients receiving continuation or maintenance therapy with fluoxetine $20 \mathrm{mg} /$ day, can be treated effectively by increasing the dose to $40 \mathrm{mg} /$ day. Conversely, Cain (31) postulating that overmedication with fluoxetine might appear as a response failure, reported 4 patients who continued to deteriorate when their dose of fluoxetine was raised, but that symptoms improved dramatically during systematic trials of lower doses. Cain noted that higher doses of fluoxetine may correlate with high plasma concentration of norfluoxetine, the active metabolite of fluoxetine, which was sometimes associated with a poor clinical response. (31).

The mechanism of this loss of efficacy of SSRI's, and fluoxetine in particular, remains unclear. One hypothesis suggests that long-term treatment with fluoxetine may cause a relative dopamine deficiency, which may respond to treatment with postsynaptic dopamine agonists (33). Our case may lend support to this theory, surrounding the fact that Ms. A developed delusional ideas, but also had reported some improvement in her mood. 
One final possible explanation for Ms. A's treatment resistance may be the contribution of her medical conditions, diabetes in particular. Her diabetes was not well controlled, based on the hemoglobin Alc level, as well as increased cholesterol/HDL and low HDL. However, the rest of her laboratory exams were normal, so it seems unlikely that her initial lack of response to fluoxetine may be attributed to her medical condition. Also, there are some reports that fluoxetine has proven effective as an antidepressant in the treatment of depression associated with serous physical illnesses, including diabetes (34).

We present the case of a 45 year old woman with depression unresponsive to fluoxetine, whose depression responded to the adjunctive addition of bupropion, but who developed frank psychosis soon after initiation of bupropion in low-moderate dose. We suggest a cautious approach in the concurrent use of bupropion and substances that interfere with its metabolism.

Vassili Arkadiev, MD

Stephen Ruedrich, MD Cleveland, $\mathrm{OH}$

\section{REFERENCES}

1. Golden RN, Nicholas LM. Bupropion. In: Sadock BJ, Sadock VA, eds. Comprehensive Textbook of Psychiatry. Baltimore: Williams \&Wilkins, 2000: 2324-2329.

2. Settle EC. Bupropion sustained release: side effect profile. J Clin Psychiatry 1998; 59: 32-36.

3. Becker RE, Dufresne RL. Perceptual changes with bupropion, a novel antidepressant. Am J Psychiatry 1982; 139: 1200-1201.

4. Goode DJ, Manninig AA. Comparison of bupropion alone and with haloperidol in schizoaffective disorder, depressed type. J Clin Psychaitry 1983; 44: 253-255.

5. Goetz CG, Tanner CM, Klawans HL. Bupropion in Parkinson's disease. Neurology 1984; 34: 1092-1094.

6. Golden RN, James SP, Sherer MA, Rudorfer MV, Sack DA, Potter WZ. Psychoses associated with bupropion treatment. Am J Psychiatry 1985; 142: 1459-1462.

7. Liberzon I, Dequardo JR, Silk KR. Bupropion and delirium (letter). Am J Psychiatry 1990; 147: 1689-1690.

8. Van-Putten T, Shaffer I. Delirium associated with bupropion (letter). J Clin Psychopharmacol 1990; 10: 234.

9. Ames D, Wirshing WC, Szuba MP. Organic mental disorders associated with bupropion in the three patients. J Clin Psychiatry 192; 53: 53-55.

10. Howard WT, Warnock JK. Bupropion-Induced psychosis (letter). Am J Psychiatry 1999; 156: 2017-2018.

11. Filteau MJ, Leblanc J, Lefrancoise S, Demers MF. Visual and auditory hallucinations with the association of bupropion and valproate (letter). Can J Psychiatry 2000; 45: 198-199.

12. Feighner JP. Mechanism of action of antidepressant medications. J Clin Psychiatry 1999; 60 (suppl): $4-13$.

13. Fuller MA, Sajatovic M. Psychotropic Drug Information Handbook. Cleveland: Lexi-Comp Inc, 2000.

14. Physicians’ Desk Reference. Motvale: Medical Economics Company, Inc, 2001.

15. DeVane CL, Laizure SC, Stewart JT, Kolts BE, Ryerson EG, Miller RL, Lai AA. 
Disposition of bupropion in healthy volunteers and subjects with alcoholic liver disease. J Clin Psychopharmacol 1990; 10: 328-332.

16. Guan XM, McBride WJ. Fluoxetine increases the extracellular levels of serotonin in the nucleus accumbens. Brain Res Bulletin 1988; 21: 43-46.

17. Lauterbach EC. Serotonin reuptake inhibitors, paranoia, and the ventral basal ganglia. Clin Neuropharmacology 1991; 14: 547-555.

18. Underleider JT, Pechnick RN: Hallucinogens. In: Lowinsin JH, Ruiz P, Millman RB, Langrod JG. Substance abuse: a comprehensive textbook. $2^{\text {nd }}$ ed. Baltimore: Williams \& Wilkins, 1992: 285.

19. Pierce PA, Peroutka SJ. Antagonist properties of d-LSD at 5-hydroxytryptamine-2 receptors (review). Neuropharmacology 1990; 3: 503-508.

20. Mandalos GE, Szarek BL. Dose-related paranoid reaction associated with fluoxetine. J Nerv Ment disease 1990; 178: 757-58.

21. Bacher NM, Ruskin P. Addition to fluoxetine to treatment of schizophrenia. Am J Psychiatry 1991; 148: 274-275.

22. Achamallah NS. Visual hallucinations after combining fluoxetine and dextromethorphan (letter). Am J Psychiatry 1992; 149: 1406.

23. Lauterbach EC. Dopaminergic hallucinosis with fluoxetine in Parkinson's diseases (letter). Am J Psychiatry 1993; 150: 1750.

24. Bourgeois JA, Thomas D, Johansen T, Walker DM. Visual hallucinations associated with fluoxetine and sertraline (letter). J Clin Psychopharmacology 1998; 18: 482-483.

25. Goodnick PJ, Goldstein BJ. Selective serotonin reuptake inhibitors in affective disordersII. Efficacy and quality of life. J Psychopharmacology 1998: 12 (Supplement B): S21-54.

26. Fava M, Schmidt ME, Zhang S, Gonzales J, Raute NJ, Judge R. Treatment approaches to major depressive disorder relapse. Part 2:reinitiation of antidepressant treatment. Psychother Psychosomathics 2002; 71(4): 195-199.

27. Ayd FJ (1991) Does a therapeutic window explain loss of therapeutic effect with fluoxetine? Int Drug Ther Newsletter 1991; 26: 33-34.

28. Rapport DJ, Calabrese JR (1993). Tolerance to fluoxetine (letter). J Clin Psychopharmacol 1993; 13: 361

29. Michelson D, Reimherr FW, Beasley CM, Wilson M. Optimal length of continuation therapy: a prospective assessment during fluoxetine long term treatment of MDD. New Research Program and Abstracts. Paper presented at the $150^{\text {th }}$ Annual Meeting of the American Psychiatric Association, San Diego, 1997.

30. Fava M, Rappe M Pava AA, Nierenberg AA, Alpert JE, Rosenbaum JF. Relapse in patients on long-term fluoxetine treatment: response to increased fluoxetine dose. J Clin Psychiatry $1995 ; 56: 52-55$

31. Cain JW. Poor response to fluoxetine: underlying depression, serotonergic overstimulation or a "therapeutic window"? J Clin Psychiatry 1992; 53: 272-277.

32. Kelly MW, Perry PJ, Holstad SG, Garvey MJ. Serum fluoxetine and norfluoxetine concentrations and antidepressant response. Ther Drug Monit 1989; 11: 165-170.

33. McGrath PJ, Quitkin FM, Klein DF. Bromocriptine treatment of relapses seen during selective serotonin re-uptake inhibitor treatment of depression. J Clin Psychopharmacology 1995; 15: 289-291.

34. Cheer SM, Goa KL. Fluoxetine: a review of its therapeutic potential in the treatment of depression associated with physical illness. Drugs 2001; 61(1): 81-110. 